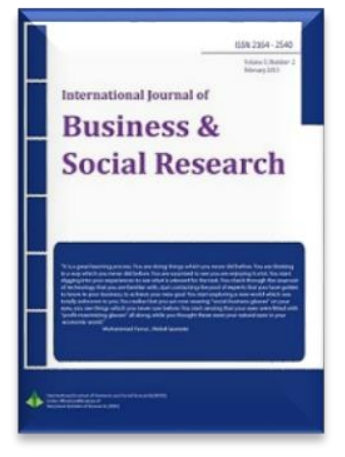

\title{
Threshold Effects of Fiscal Policy on Economic Activity in Developing Countries
}

\begin{abstract}
Salma Slimani ${ }^{1}$
ABSTRACT

The aim of this paper is to investigate the relationship between fiscal policy and economic growth for a panel of 40 developing countries for the period $1990-2012$ with a focus on a comparative analysis between Morocco and the panel. The variables used are real GDP, budget deficit, current government spending, national saving, inflation rate, total investment, public debt and current account balance. The main findings are: First, there is evidence of a double threshold effect of the fiscal balance. When exceeding a budget deficit level of $4.8 \%$ of GDP or a fiscal surplus level of $3.2 \%$ of GDP, economic growth is negatively affected. Second, the sign of the relationship between budget deficit and economic growth is conditioned by the level of total investment. For values of total investment higher than $23 \%$, it follows that there is a positive relationship. However, it becomes negative, when investment falls below this threshold. Third, from Morocco's perspective, analysis of threshold effects suggested that above $4.8 \%$ of budget deficit, average growth rate falls by $2.1 \%$, while median growth falls by $1.5 \%$.
\end{abstract}

Keywords: Developing countries, economic growth, fiscal deficit, investment, threshold effects.

JEL Codes: $\mathrm{C} 51, \mathrm{H} 39, \mathrm{H} 62, \mathrm{O} 23, \mathrm{O} 49$.

Available Online : 03-04-2016

This is an open access article under Creative Commons Attribution 4.0 License, 2016.

\section{$1.0 \quad$ INTRODUCTION}

In both theory and evidence, there are controversial thoughts and debates that focus on the impact of fiscal deficit on economic growth. Since the nineties, this subject becomes highly debated in the literature. Barro (1990) is considered as one of the most important pioneers in the field. He suggests a simple endogenous growth model and shows that the share of government spending in GDP may have a significant effect on economic growth. Later, Bertolat and Drazen (1993) point out that this relationship might be non-linear. Starting in the years 2000, it can be observed a significant body of empirical and theoretical work taking into account the non-linearity that can prevail on the relationship between ${ }^{1}$ Ph.D. researcher, Department of economics, Mohammed V Rabat -Agdal University, Faculty of Juridical, Economic and Social
Sciences, Morocco. E-mail: slimani.salma11@gmail.com. 
growth and budget deficit [Minea and Villieu (2008), Adam and Bevan (2005), Tanimoune, Combes and Plane (2008) and Minea and Villieu (2012)]. These authors try to identify anti-Keynesian effects, which are related to the persistence of high fiscal contractions. However, there is still no consensus about the threshold of fiscal deficit that authorities must not exceed.

The European debt crisis in 2010 shook the global economy when some indebted countries in Euro area, which had been maintaining high levels of debt and fiscal deficit, faced the default on payment of the public debt and on its interest. Even more worrying is the fact that most of the projected deficits in a number of industrial countries are structural and unsustainable [Cecchetti, Mohanty and Zampolli (2010)]. Although the crisis mainly pertained to European countries, the concern of a similar public debt crisis is also shared by other low-income countries, and even more heavily in a context of an economies suffering from macroeconomic vulnerabilities, output below its potential and high levels of unemployment.

The increasing budget deficit and public debt in Morocco during the past four years raises nowadays the concern of politicians as well as researchers. The Moroccan government is convinced of the major role that plays fiscal policy as a stabilization tool, the only remaining question is finding the appropriate threshold that should not be exceeded. Euro convergence criteria in the Maastricht Treaty (1993) outlined that the ratio of the annual general government deficit relative to gross domestic product (GDP) at market prices, must not exceed $3 \%$ at the end of the preceding fiscal year. Even though it is hardly justified ${ }^{2}$, Moroccan politicians try to bring the deficit near to the $3 \%$ threshold. But is it really the most relevant threshold for the Moroccan case?

From within the lineage of recent empirical studies, this research paper tries to provide some possible answers to the question asked through identifying the nature of the relationship between budget deficit and economic growth for a panel of 40 developing countries. Using annual data over the period $1990-$ 2012, the paper concludes with the existence of anti-Keynesian effects that are associated to a fiscal deficit exceeding $4.8 \%$ of GDP, but also a negative impact of a fiscal surplus on economic growth may occur when exceeding the threshold of $3.2 \%$ of GDP. Results show also that the level of total investment is a major determinant in the relationship between the budget deficit and growth: when total investment exceeds the threshold of $23 \%$ of GDP, then the budget deficit is positively correlated to economic growth, whereas it is negatively correlated to growth when total investment falls below the threshold. Therefore, countries concerned by the study should set priorities in favour of productive investment and should implement appropriate mechanisms to prevent exceeding the thresholds found. The Moroccan case represents, notably, an effective framework to consider the relevance of previous results. Using data spanning from 1980 to 2010, the findings remain consistent. In fact, the behavior of economic growth varies depending on variations in the budget deficit: when the budget deficit exceeds the $4.8 \%$ threshold, median growth falls sharply by $1.5 \%$, whereas average growth falls even strongly by $2.1 \%$.

This paper is organized as follows: The next section will briefly return to the theoretical and empirical studies around this subject. Section 3 outlines the methodological approach, data employed in the study of the econometric analysis of both linear and non-linear model. The threshold analysis uses the threshold estimation technique outlined by Hansen (1999). Section 4 presents, first, the estimation results of the linear model. The latter allows identifying the economic variables that affect real GDP growth. Second, the threshold analysis was carried out by considering sequentially, the overall fiscal deficit and total investment as threshold variables. Third, From Morocco's perspective, an overview of the historical behavior of fiscal policy and economic growth is presented to further see how Moroccan real GDP growth behaves as the fiscal deficit varies. Section 5 concludes the paper and summarizes its main findings.

\footnotetext{
${ }^{2}$ It has been argued by many economists that the threshold of $3 \%$ was set arbitrarily and has no basis but the circumstances as European fiscal deficits in the early 90 s were less than 3\%. See Buiter, Corsetti and Roubini (1993), and Buiter (2006) for more details.
} 


\subsection{PRIOR LITERATURE}

Before the advent of the Keynesian theory, governments tried to implement every effort to reach the fiscal balance. But with the Keynesian theory, this dogma was questioned. Keynes argued that there is a positive relationship between budget deficit and economic growth. Governments are encouraged to run deficits during recession as it will help to stabilize the economy. On the other hand, there is the liberal theory that argued the opposite. Their main argument is related to the crowding out phenomenon. More recently, Barro ${ }^{3}$ (1990) presented an endogenous growth model which is considered now as a fundamental reference. The model highlights an explicit link between government spending and longrun economic growth in the context of endogenous growth, and shows that we can determine an optimal public spending. At this point, any additional expenditure may affect economic growth negatively. Therefore, if public expenditures exceed their optimal level, there will be a negative correlation, and conversely, if public expenditures fall below their optimal level, there will be a positive correlation. However, there are only a few theoretical studies that deal with non-linear effects of fiscal deficits in growth models. By way of example reference, there is Perotti's model (1999) where non-linear effects of fiscal policy are identified, but not in a growth context. Their model shows that government expenditure may have positive "keynesian" effects or reversed effects depending on the initial level of public debt ${ }^{4}$. So, in high-debt contexts, a fiscal consolidation may reduce the risk of defaulting on sovereign debt, thus improving confidence and increasing private consumption. By using Barro's (1990) model, Greiner and Semmler (2000) removed the balanced budget assumption and analyzed different budgetary regimes. They claimed that the impact of deficit financed increase on growth depends on the budgetary regime the government operates within. Thus, governments can generate positive growth effects of a public deficit on the growth rate only for a given debt/capital ratio and if the deficit is used primarily for public investment. Ghosh \& Mourmouras (2004) extended the Greiner and Semmler framework to include welfare analysis. Their main objective is to analyze the growth and welfare implications of the golden rule of public finance. They showed that optimal fiscal policy depends on the particular budgetary regime considered.

In Barro's (1990) model, neither public debt, nor public deficits are allowed. Thus, all public expenditures are productive and growth-enhancing. Minea and Villieu (2012) tried to examine the nature of fiscal deficit effects on growth by extending the Barro (1990) endogenous growth model. They introduced productive public spending, public deficit and debt in the model to study non-linear effect of fiscal policy in the short and long run, and showed in their model how the effect of public deficit shifts from one condition to another depending on the multiplicity of balanced growth paths. In the long run, if public deficits are devoted to public investment, we will be in presence of a lower balanced growth path. On the other hand, in the short run, the effect of public deficit depends on both the level of growth's steady states and the initial level of public debt.

Beyond the theoretical debates, the study of the relationship between fiscal policy and economic growth received much attention in the empirical literature. However, it is difficult to provide an unclouded characterization of what the appropriate behavior of fiscal policy should be. Empirical results are quite often inconsistent and sometimes contradictory. This discordance in terms of evaluation and finding are mainly due to multifarious factors such as time dimension, types of governments, methods of analysis as well as econometric methods that are used. By not taking into account the non-linear hypothesis, a large body of empirical literature on fiscal policy falls under the Keynesian theory, while other studies claim that having a balanced budget is more desirable as it will help the economy to grow faster over time. In order to explain the "productivity slowdown" in the 1970s for the United States, Aschauer (1989)

\footnotetext{
3 In Barro's model (1990), all public expenditures are productive and goes for public investment increasing marginal productivity of private capital, as for example infrastructure, schools, sanitation, property rights, etc. Investment public spending is financed through income taxes, complement private investments. Thus, since public investments raise the productivity of private investments, higher taxes can be associated with an increase or a decrease in overall growth.

4 In contrast with Perotti (1999), Giavazzi, Jappelli \& Pagano (2000) found no evidence of a small impact of high or rapidly growing public on non-linear effects of fiscal policy, but found instead that during periods of rapidly growing public debt the impact of taxes and government spending on national savings is significantly different.
} 
indicates, by using time series, a positive relationship between government expenditure and economic growth: a $1 \%$ increase in the ratio of public to private capital stocks raises productivity by $0.39 \%$. However, the study points out the importance of how the public capital is composed. The core infrastructure (streets, highways, airports, mass transit, sewers, water systems, etc.) is the most important component in determining productivity. Almost same conclusion is derived from the research made by Easterly and Rebelo (1993) for the period going from 1970 to 1988. By using panel data for 28 countries and crosssectional data for 100 countries, they found that the share of public investment in transport and communication is robustly and positively correlated with growth. Public outlays on infrastructure investment raise growth. Contrariwise, agriculture investment is consistently negatively correlated with growth, while Public enterprise investment has no effect on growth. Based on the research made by Benos (2009), the previous result related to infrastructure spending was again proven to be accurate. The author used panel data on 14 EU countries during 1990-2006 and found also that public expenditures on property rights protection enhance growth, while government expenditures on human capital have no effect on growth.

On the opposite side, other studies agreed with the liberal theory thought, in which fiscal deficits have a negative effect on economic growth. A theory that gives support to the budgetary rule assuming that obtaining a balanced budget is considered as the only way to maintain a sustainable growth over time. Within the same framework, Gupta, Clements, Baldacci, Mulas-Granados (2005) found for a panel of 39 low-income countries during the period 1990 - 2000 that a balanced budget stance leads generally to an increase in economic growth in both short and long terms. The study pointed out also the significant importance that holds the composition of public spending: when wages accounts for a big share of public expenditure, growth falls dramatically, while governments which concentrate their spending on capital and nonwage goods and services are more likely to experience a significant increase in growth. With an emphasis on the causal relationship lying between budget deficit and economic growth, keho's study (2010) focused on the member countries of the West African Economic and Monetary Union during the period $1980-2005$. The results suggest that for three countries there is no causality link between budget deficit and growth, whereas for the remaining four countries deficits exert a negative impact on growth.

Consistent with the Ricardian equivalence hypothesis ${ }^{5}$, other studies claimed that there is neutral relationship between fiscal deficit and growth ${ }^{6}$. From Malaysia's perspective, Abd Rahman's study (2012) gives support to the previous hypothesis. By using an Autoregressive Distributed Lag modeling, it was found that there is no long-run relationship between fiscal deficit and growth, and that only the GDP and productive spending can bring the economy to its equilibrium state in case where the Malaysian economy undergoes a shock.

Differences in terms of results may be due to default in taking into account the non -linearity hypothesis as fiscal deficits may have either traditional Keynesian effects or reversed effects. Nevertheless, more recently, a major importance was given to this hypothesis. There is, for instance, Adam and Bevan's research paper (2005) where the authors try to identify thresholds effects of fiscal deficit on growth for a panel of 45 developing countries for the period 1979 - 1999. The study indicates that fiscal deficits are associated with robust non-linear effects on growth and finds evidence of a threshold effect at a level of the deficit around $1.5 \%$ of GDP. When reducing deficits to this level, there appears that governments enjoy faster growth expansion; this effect reverses itself when exceeding the determined threshold. Nearly, the same conclusion was found in a research made by Tanimoune, Combes and Plane (2008) on the pattern of public debt with a focus on the member countries of the West African Economic and Monetary Union during the period 1986 - 2002. The study indicates a threshold effect at a debt level of $83 \%$. There appears to be a growth-shrinking to exceeding debt at this level. As regards for OECD countries, Minea and Villieu (2008) carried out a research to determine if there can be a non-linear effect of fiscal deficit

\footnotetext{
5 See Barro (1974) for more details on Ricardian equivalence.

${ }^{6}$ There is, however, an extensive empirical literature that has found evidence against this hypothesis [Feldstein (1986), Kotlikoff, Razin and Rosenthal (1988), Modigliani and Sterling (1990), Dalamagas (1992), Graham (1995), Evans (1993), Cardia (1997) and Banzhaf and Oates (2012)].
} 
on growth, depending on the public debt to GDP ratio. Results confirm that budget deficits are growthincreasing only for low-indebted economies as long as the debt burden may be absorbed by a cut in government consumption. In contrast, for further high debt values, raising deficits are growthdecreasing since government can no longer reduce public consumption and the budget adjustment will inevitably rely on decreasing productive spending. Hence above a certain level of public debt, raising deficits becomes growth-reducing. The study indicates a threshold for a debt level standing at around 90\%. This is consistent with the Rogoff and Reinhart's (2010) analysis. It was also claimed that exceeding $90 \%$ of public debts will result in impeding the process of economic growth. On the basis of a database covering forty-four countries spanning about two hundred years, the study finds evidence that growth for countries above $90 \%$ of public debt is $-0.1 \%$ on average. A result which has been rectified in Herndon, Ash and Pollin's review study (2013) reporting 2.2\% on average real GDP growth, a drop of only a $1 \%$ in growth.

These last studies indicate that fiscal deficits are in general associated with strong non-linear effects on growth. In high debt contexts, growth drops off sharply. And inversely, for low debt values, growth remains high. Hence, this paper aims to investigate fiscal policy from the perspective of a non-linearity by using the panel threshold regression technique proposed by Hansen (1999).

\subsection{METHODOLOGY, DATA AND ECONOMETRIC ESTIMATION}

This section empirically evaluates the fiscal policy initially by considering that the relationship between fiscal policy and economic growth is a linear one, and then trying to determine the economic variables that affect growth. Secondly, the threshold effects analysis is conducted assuming a priori that this relationship might be non-linear by considering sequentially the overall fiscal deficit and total investment as threshold variables.

The study covers a panel of forty ${ }^{7}$ developing countries for the period $1990-2012$. The sample selection was made a priori depending on data availability. Indeed, Hansen's method (1999) is valid only for a balanced panel. The choice of period and annual data is determined by their availability since 1990 and the lack of monthly and quarterly data.

\subsection{LINEAR MODEL ESTIMATION}

Appendix B provides a summary of the statistics of the data and defines the variable mnemonics used later in the paper. In this sub-section the following empirical growth model is estimated:

$G D P_{i t}=\mu_{i}+a_{1} G E_{i t}+a_{2} N S_{i t}+a_{3} F D_{i t}+a_{4} I N V_{i t}+a_{5} I N F_{i t}+\varepsilon_{i t}$

Where $(i, t)$ captures the cross-sectional and temporal dimensions of the panel, $\mu_{i}$ represents the countryfixed effects and $\varepsilon_{i t}$ is a stochastic error term. The econometric model is a fixed effects model where the relationship between the dependent variable and the explanatory variables are supposed to be identical for the countries in question. Using a fixed effects model will enable to take into consideration differences in terms of economic structure and history for each country. Choosing this specification is backed by the Hausman ${ }^{8}$ and the Breusch \& Pagan ${ }^{9}$ test. As a matter of fact, it was concluded that the choice of "Within" estimator is required. Individual-specific means are removed to eliminate the individual effect.

The expected sign for $\alpha_{5}$ is negative, while for $\alpha_{2}$ and $\alpha_{4}$ it is positive:

\footnotetext{
7 Details of country coverage, data source and descriptions are provided in Appendix (A and B).

${ }^{8}$ The Hausman test probability is less than $10 \%$ ( $P$-value $=0.0002 \%<10 \%$ ), implying that the fixed effects model is preferred over random effects model.

9 This test allows examining the significance of the individual specific effects. It is based on the residues obtained by the OLS. The probability of the Breusch \& Pagan statistic showed that fixed effects are significant at the $5 \%$ level $(P$-value $<0,05)$. And therefore, a fixed effects model is preferred.
} 


$$
\begin{gathered}
G D P_{i t}=f\left(G E_{i t}, N S_{i t}, F D_{i t}, I N V_{i t}, I N F_{i t}\right) \\
?+?+-
\end{gathered}
$$

As regards the domestic saving, classical and neoclassical theories show their importance for economic activity. When allowing for investment financing, savings enable for maintaining productivity growth. Aghion, Comin and Howitt (2006) found that for poor countries, national saving plays an important role in attracting foreign investment and therefore to promote innovations. Thus, local savings matter for economic growth. Hence, a positive sign is expected for this variable. Regarding the fiscal deficit and the government current expenditure, it seems a little equivocal to predict a priori, under the linearity assumption, their impact on economic growth. While Keynesian economies showed their beneficial effect, liberal economies indicated the opposite. Similarly for empirical literature, findings are mitigated and contradictory. Concerning investment, it is, as is well known, a determining factor of growth and productivity, for both the neoclassical and the Keynesian economies. Furthermore, it may generate, in accordance with the endogenous growth theory, positive externalities. As for inflation, Liberals consider it as highly injurious for economic growth. Besides, a wide range of empirical studies indicate a negative relationship between inflation and growth. Khan and Senhadji (2001) claimed the presence of a threshold effect of inflation on growth. Both industrialized and developing countries caught their interest. For the industrialized ones, when inflation exceeds $1-3 \%$ it has a negative impact on growth. Whereas, for developing countries, inflation has constantly a negative impact on productivity and it does widen even more when inflation surpasses $11-12 \%$. Therefore, a negative sign for inflation is expected.

\subsection{THRESHOLD EFFECTS ANALYSIS}

Before moving to a more systematic analysis, it is proposed to explore a simple scatter plot visualizing the relationship between budget deficit and GDP growth. The existence of threshold effects assumes implicitly that this relationship is non-linear. Figure 1 illustrates this relation in the form of a cloud diagram. The non-linear function is plotted, as a locally weighted smoothing ${ }^{10}$ (lowess smoother) with a "bandwidth" setting of 0.5 , to identify graphically the existence of non-linearities.

Figure 1: Fiscal deficit and GDP Growth in 40 developing countries, 1990-2012

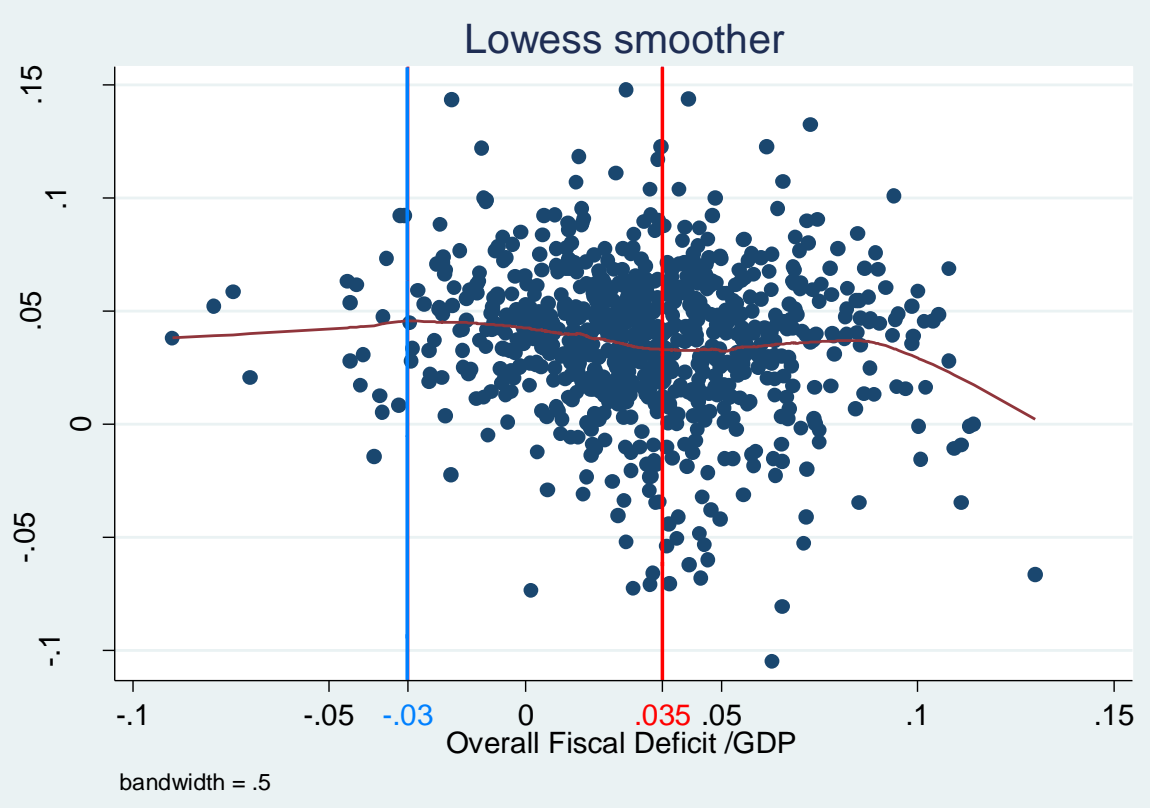

\footnotetext{
${ }^{10}$ It is a smoothing method that tends to follow the data. Basically, the main idea is to create a new variable, so that each observation in the data may correspond to a smoothed value. The smoothed values are obtained from a regression, growth of GDP in the fiscal deficit. This regression is weighted so that each point receives the highest weight.
} 
It can be drawn from figure 1 that a linear representation may hide important and relevant nonlinearities at many budget deficits' levels. Moreover, it is clear that high budget deficit is associated with a very low GDP growth. However, growth payoffs start as the deficit falls from around 3.5\%. The existence of a threshold effect implies not only a variation in the slope of the regression line, but also a sign switch in the relationship. For a budget deficit value below a given threshold, there appears to be a favourable effect on economic activity, this effect inverse itself for higher fiscal deficit values.

Given the high degree of dispersion, as observed in the scatter plot, this attempt to view the data is just preliminary; hereafter the findings are submitted to a more systematic analysis using econometric methods.

\section{A BRIEF DESCRIPTION OF THE ECONOMETRIC APPROACH: HANSEN (1999)}

The panel threshold regression model with individual-specific effects proposed by Hansen (1999) will be used below to characterize the relationship between growth and fiscal policy. Estimating the PTR requires the minimization of the sum of squared errors according to the following equation:

$$
y_{i t}=\mu_{i}+\alpha_{1} x_{i t} l\left(q_{i t} \leq \gamma\right)+\alpha_{2} x_{i t} l\left(q_{i t}>\gamma\right)+\varepsilon_{i t}
$$

Where $q_{i t}$ is the threshold variable ${ }^{11}, \gamma$ refers to the threshold, I(.) is an indicator function of the "regimes" transition which equals 1 when the condition in parenthesis is satisfied and o otherwise. Although, in this model, we have a single threshold where the observations are divided into two regimes depending on whether the threshold variable $\mathrm{q}_{i t}$ is smaller or larger than the threshold parameter $\gamma$, we can generalize the model to a more larger specification with $r$ thresholds (i.e. $r+1$ regimes) as illustrated below:

$y_{i t}=\mu_{i}+a_{1} x_{i t} \mathrm{l}\left(q_{i t} \leq \gamma_{1}\right)+a_{2} x_{i t} \mathrm{l}\left(\gamma_{1}<q_{i t} \leq \gamma_{2}\right)+\ldots a_{r} x_{i t} \mathrm{l}\left(\gamma_{\mathrm{r}-1}<q_{i t}\right)+\varepsilon_{i t}$

Estimating this model is carried out by stages. First, the individual fixed effects $\mu_{\mathrm{i}}$ should be removed by eliminating individual specific means, and then we apply the ordinary least squares procedure. Afterwards, we can compute the sum of squared residuals referred to as $S_{1}(\gamma)$ :

$$
\mathrm{S}_{1}(\gamma)=\sum_{i=1}^{N} \sum_{t=1}^{T} \hat{\varepsilon}_{i t}^{2}
$$

The threshold parameter $\gamma$ is then estimated by minimizing $S_{1}(\gamma)$.

$$
\hat{\gamma}=\operatorname{Arg} \operatorname{Min}_{\gamma} \mathrm{S}_{1}(\hat{\gamma})
$$

As Hansen (1999) stresses, the sum of squared error function is a step function with at most nT steps. Thus, the minimization problem can be reduced to a search over values of $\gamma$ equal to the distinct values of $\mathrm{q}_{i t}$ in the sample. The next step consists of testing whether the identified threshold is statistically significant or not. The null hypothesis describes a linear specification and can be writen as: $H_{0}: \alpha_{1}=\alpha_{2}$. We use the likelihood ratio test verify this hypothesis:

$$
\mathrm{F}_{1}=\frac{S_{0}-S_{1}(\gamma)}{\sigma^{2}}
$$

Where $S_{0}$ indicates the sum of the squared residuals of the linear model, $S_{1}(\gamma)$ is the sum of the squared residuals of the model with a single threshold, and $\sigma^{2}=S_{1}(\gamma) / n(T-1)$. However, Hansen emphasizes that the distribution of this statistic $F_{1}$ has a non-standard character since that the PTR model contains unidentified nuisance parameters under $\mathrm{H}_{0}$, and propose, in order to resolve this problem, to simulate by Bootstrap the asymptotic distribution of the statistic $F_{1}$. When a single threshold effect is attested to be significant, the same procedure can be applied to the general model in order to determine the number of regimes. In this case, the new null hypothesis consists of testing a specification with $r$ regimes versus a specification with $r+1$ regimes. For determining the number of thresholds, Hansen advocates to start

${ }^{11}$ The threshold variable is assumed to not be time invariant, and it cannot be contemporaneous endogenous variable. 
by testing one threshold versus two, then two versus three, and so forth. The procedure stops when the null hypothesis is not rejected.

\subsection{RESULTS AND DISCUSSION}

\subsection{LINEAR ESTIMATION RESULTS}

Appendix $C$ reports the estimation results. On the basis of the information criterion ${ }^{12}$, the best model is (3). The p-value of the first Fisher test is below 5\% (0.000), which attests to the significance of the explanatory variables. The second Fisher test shows the wide heterogeneity of individuals in the form of fixed effect, as the $\mathrm{p}$-value is lower than $5 \%(0.000)$. All the variables have the signs that were previously anticipated. The variables FD, INV and INF are significant at a $1 \%$ level. GE variable is significant at the 5\% level. And finally, the variable NS is significant at the $10 \%$ level. Current government expenditure is negatively correlated with growth and thus its increase can hinder the process of growth. A high ratio of national savings to GDP has a favourable impact on economic activity. Fiscal deficit has a negative sign, which means that raising deficit is growth reducing. As for total investment, it has a positive sign and hence a positive effect on GDP growth. And finally, inflation has a negative sign, and thus having high inflation rates have an adverse economic impact, with harmful consequences for growth.

\subsection{FISCAL DEFICIT AS A THRESHOLD VARIABLE}

This threshold least square regression model is specified as follows:

$$
\begin{aligned}
G P_{i t} & =\mu_{i}+\alpha_{1} G E_{i t-1}+\alpha_{2} F_{i t-1}+\alpha_{3} I N V_{i t-1}+\alpha_{4} I N F_{i t-1}+\beta_{1} N S_{i t-1} I\left(F D_{i t-1} \leq \gamma_{1}\right) \\
& +\beta_{2} N S_{i t-1} I\left(\gamma_{1}<F D_{i t-1} \leq \gamma_{2}\right)+\beta_{3} N S_{i t-1} I\left(\gamma_{2}<F D_{i t-1}\right)+\varepsilon_{i t}
\end{aligned}
$$

Where $\mu_{i}$ represents the country-fixed effects, $(i, t)$ captures the cross-sectional and time dimensions of the panel, and $\varepsilon_{i t}$ is a stochastic error term.

In order to determine the number of threshold effects, the model above is estimated by the least squares method, sequentially, for one, two and three threshold effects. The test statistics F1, F2 and F3, set out together with their bootstrap p-values ${ }^{13}$ are presented in the table 1 . The statistic F1 which made a reference to the test for a single threshold effect is significant at a $5 \%$ level with a bootstrap p-value of 0.016. The test for a double threshold effect $F_{2}$ is even more significant at a $1 \%$ level with a bootstrap pvalue of 0.006 . Finally, the test for a triple threshold effect $F_{3}$ may be considered as not statistically significant at the $5 \%$ level as the bootstrap p-value is equal to 0.050 . These tests allow concluding that there are two thresholds effect of fiscal deficit on economic productivity according to the empirical growth regression model. The two thresholds estimated values and their asymptotic confidence intervals 95\% are reported in table 2 . The point estimates are -0.032 and 0.048 . Appendix E, F and $\mathrm{G}$ present the likelihood ratio function $\mathrm{LR}_{1}(\gamma), \mathrm{LR}_{2}^{r}(\gamma)$ and $\mathrm{LR}_{1}^{r}(\gamma)$, respectively, corresponding to estimates for $\gamma_{1}, \gamma_{1}^{r}$ and $\gamma_{2}^{r}$. The point estimates are the value of $\gamma$ at which the likelihood ratio reached the zero axis.

\begin{tabular}{lr}
\hline \multicolumn{2}{c}{ Table $1:$ Threshold effects tests for the fiscal deficit } \\
\hline Test for a single threshold effect & 16.001 \\
\hline$F_{1}$ & 0.016 \\
P-Value & $(11.714 ; 13.745 ; 18.262)$ \\
(10\%, $5 \%, 1 \%$ critical values) & 18.382 \\
\hline Test for a double threshold effect & 0.006 \\
\hline F $_{2}$ P-Value & $(11.599 ; 13.175 ; 17.322)$ \\
\hline
\end{tabular}

\footnotetext{
12 The AIC (Akaike Information Criterion) outputs for model selection are shown in Appendix C. The BIC (Bayesian Information Criterion) outputs for model selection are shown in Appendix $C$.

13500 bootstrap replications were used for each test.
} 


\begin{tabular}{lr}
\hline Test for a triple threshold effect & 14.160 \\
\hline$F_{1}$ & 0.050 \\
P-Value & $(11.850 ; 14.124 ; 18.805)$ \\
\hline
\end{tabular}

Table $\mathbf{2}$ : Threshold estimates for the fiscal deficit

\begin{tabular}{rrr}
\hline & Estimate & $95 \%$ Confidence Interval \\
\hline$\gamma_{1}^{r}$ & -0.032 & {$[-0.032 ; 0.055]$} \\
$\gamma_{2}^{r}$ & 0.048 & {$[0.017 ; 0.055]$} \\
\hline
\end{tabular}

The point estimates are -0.032 and 0.048 . Figures ( 5,6 and 7) present the likelihood ratio function $L_{1}(\gamma)$, $\operatorname{LR}_{2}^{r}(\gamma)$ and $\operatorname{LR}_{1}^{r}(\gamma)$, respectively, corresponding to estimates for $\gamma_{1}, \gamma_{1}^{r}$ and $\gamma_{2}^{r}$. The point estimates are the value of $\gamma$ at which the likelihood ratio reached the zero axis. The regression coefficient estimates and their standard deviations are shown in the table 3.

Table 3: Regression estimates for a double threshold effect of the fiscal deficit

\begin{tabular}{|c|c|c|c|c|}
\hline Explanatory Variables & $\begin{array}{r}\text { Coefficient } \\
\text { estimate }\end{array}$ & OLS & $\begin{array}{r}\text { Standard- } \\
\text { errors }\end{array}$ & $\begin{array}{r}\text { White-corrected Standard- } \\
\text { errors }\end{array}$ \\
\hline$I N V_{\text {it- } 1}$ & 0.003 & & 0.028 & 0.028 \\
\hline$G E_{i t-1}$ & -0.023 & & 0.027 & 0.028 \\
\hline$F D_{\text {it-1 }}$ & $-0.237 * * *$ & & 0.054 & 0.053 \\
\hline INF it-1 & -0.00084 & & 0.00078 & 0.00061 \\
\hline$N S_{i t-1} I\left(F D_{i t-1} \leq-0.032\right)$ & $-0.115^{* * *}$ & & 0.047 & 0.056 \\
\hline$N S_{i t-1} I\left(-0.032<F D_{i t-1} \leq 0.048\right)$ & $0.056 * *$ & & 0.030 & 0.033 \\
\hline$N S_{i t-1} I\left(0.048<F D_{i t-1}\right)$ & $0.148 * * *$ & & 0.035 & 0.037 \\
\hline
\end{tabular}

The Student's t-test ${ }^{14}$ served out to test the significance of the non-linear regression slope estimates. The variables FD and NS are the only significant ones. The ratio of the budget deficit / GDP lagged by one period $\left(F D_{i t-1}\right)$ has a negative impact on GDP growth. Results indicate also that when the ratio of budget deficit / GDP approaches 0.048 starting from the highest deficit value of 0.13 , domestic savings $N S_{\text {it- } 1}$ have a positive effect on growth with the coefficient estimate of 0.148 . And conversely, domestic savings have a positive impact on growth, but with a smaller coefficient equal to 0.056 , only for countries being close from a balanced budget with a deficit lower than 0,048 and a surplus not exceeding 0.032 . And finally, if the surplus exceeds the value of 0.032 , then domestic savings have a negative impact on growth. The percentages of countries belonging to each of the three defined regimes in each year are reported in the table 4. This distribution allows seeing the countries division per year according to the pension deficit.

\begin{tabular}{|c|c|c|c|c|c|c|c|c|c|c|c|c|}
\hline \multicolumn{13}{|c|}{ Year } \\
\hline Reg & me & 1991 & 1992 & 1993 & 1994 & 1995 & 1996 & 1997 & 1998 & 1999 & 2000 & 2001 \\
\hline $1^{\text {st }}$ & $\mathrm{FD}_{\mathrm{it}-1} \leq-0.032$ & 0 & 3 & 0 & 3 & 0 & 0 & 0 & 3 & 3 & 3 & 0 \\
\hline $2^{\text {nd }}$ & $-0.032<F D_{\text {it }-1} \leq 0.048$ & 90 & 75 & 80 & 78 & 73 & 80 & 70 & 78 & 60 & 75 & 80 \\
\hline $3^{\text {rd }}$ & $0.048<F D_{\text {it-1 }}$ & 10 & 23 & 20 & 20 & 28 & 20 & 30 & 20 & 38 & 23 & 20 \\
\hline \multicolumn{13}{|c|}{ Year } \\
\hline \multicolumn{2}{|c|}{ Regime } & 2002 & 2003 & 2004 & 2005 & 2006 & 2007 & 2008 & 2009 & 2010 & 2011 & 2012 \\
\hline $1^{\text {st }}$ & $\mathrm{FD}_{\mathrm{it}-1} \leq-0.032$ & 0 & 0 & 0 & 0 & 3 & 10 & 5 & 5 & 0 & 3 & 3 \\
\hline $2^{\text {nd }}$ & $-0.032<F D_{i t-1} \leq 0.048$ & 78 & 68 & 73 & 88 & 83 & 80 & 80 & 80 & 68 & 68 & 70 \\
\hline $3^{\text {rd }}$ & $0.048<F D_{i t-1}$ & 23 & 33 & 28 & 13 & 15 & 10 & 15 & 15 & 33 & 30 & 28 \\
\hline
\end{tabular}

The percentage of countries which fall into the first regime varies from $0 \%$ to $10 \%$ over the years. The percentage of countries, in the second regime, ranges from $60 \%$ to $90 \%$, and finally, in the third regime, it varies from $10 \%$ to $33 \%$. It can be observed that most countries fall into the second regime, and this is valid

\footnotetext{
14 When Student's t-test statistic is greater than the value read in the student's table $(1.96$ at the $5 \%$ level and 1.64 at the $10 \%$ level), the null hypothesis of the non-significance of the parameters is rejected.
} 
for all years. It is interesting to note that the highest number of countries with a budget deficit exceeding the level of $4.8 \%$ is observed in 2010 .

\subsection{INVESTMENT AS A THRESHOLD VARIABLE}

The following threshold least square regression model will be estimated:

$G D P_{i t}=\mu_{i}+\alpha_{1} G E_{i t-1}+\alpha_{2} N S_{i t-1}+\alpha_{3} I N V_{i t-1}+\alpha_{4} I N F_{i t-1}+\beta_{1} F D_{i t-1} I\left(I N V_{i t-1} \leq \gamma_{1}\right)+\beta_{2} F D_{i t-1} I\left(\gamma_{1}<I N V_{i t-1}\right)+\varepsilon_{i t}$

Where $\mu_{i}$ represents the country-fixed effects, $(i, t)$ captures the cross-sectional and time dimensions of the panel, and $\varepsilon_{i t}$ is a stochastic error term.

\begin{tabular}{lr}
\hline \multicolumn{2}{c}{ Table 5 : Threshold effects tests for investment } \\
\hline Test for a single threshold effect & 18.687 \\
\hline$F_{1}$ & 0.002 \\
P-Value & $(11.148 ; 12.421 ; 15.649)$ \\
$(10 \%, 5 \%, 1 \%$ critical values) & 3.271 \\
Test for a double threshold effect & 0.876 \\
\hline F $_{2}$ & \\
P-Value & $(10.446 ; 12.295 ; 16.357)$ \\
(10\%, $\%, 1 \%$ critical values) & 2.086 \\
Test for a triple threshold effect & 0.968 \\
\hline F 1 & $(9.062 ; 10.348 ; 12.884)$ \\
\hline
\end{tabular}

\begin{tabular}{|c|c|c|}
\hline \multicolumn{3}{|c|}{ Table 6 : Threshold estimates for investment } \\
\hline & mate & 95\% Confidence Interval \\
\hline$\gamma_{1}$ & 0.236 & {$[0.212 ; 0.250]$} \\
\hline
\end{tabular}

The same procedure will be adopted. The test statistics F1, F2 and F3, set out together with their bootstrap $p$-values ${ }^{15}$, are presented in the table 5 . The statistic $F_{1}$ which refers to the test for a single threshold effect is the only significant statistic at a $1 \%$ level with a bootstrap p-value of 0.002 . Both tests for a double threshold effect $F_{2}$ and for a triple threshold effect $F_{3}$ are not significant at the $5 \%$ level. These tests allow for concluding that there is a single threshold effect for investment. The threshold estimate with its asymptotic confidence interval $95 \%$ is reported in table 6.

The point estimate is 0.236 . Appendix $\mathrm{H}$ presents the likelihood ratio function $\mathrm{LR}_{1}(\gamma)$ corresponding to the estimate for $\gamma_{1}$. The regression coefficient estimates and their standard deviations are showed in the table 7.

\begin{tabular}{|c|c|c|c|c|}
\hline Explanatory Variables & $\begin{array}{r}\text { Coefficient } \\
\text { estimate }\end{array}$ & OLS & $\begin{array}{r}\text { Standard- } \\
\text { errors }\end{array}$ & $\begin{array}{r}\text { White-corrected Standard- } \\
\text { errors }\end{array}$ \\
\hline$N S_{i t-1}$ & $0.062 * * *$ & & 0.030 & 0.032 \\
\hline$G E_{i t-1}$ & -0.032 & & 0.027 & 0.027 \\
\hline INV ${ }_{\text {it-1 }}$ & -0.024 & & 0.029 & 0.034 \\
\hline$I_{N F}$ it-1 & -0.0008 & & 0.0008 & 0.0006 \\
\hline$F D_{\text {it-1 }} I\left(I N V_{\text {it-1 }} \leq 0.236\right)$ & $-0.137 * * *$ & & 0.047 & 0.042 \\
\hline $\mathrm{FD}_{\text {it-1 }} \mathrm{I}\left(0.236<\mathrm{INV}_{\mathrm{it}-1}\right)$ & $0.167^{* * *}$ & & 0.069 & 0.076 \\
\hline
\end{tabular}

\footnotetext{
15500 bootstrap replications were used for each test.
} 
Similar to the previous analysis, The Student's t-test ${ }^{16}$ test the significance of the non-linear regression slope estimates. The coefficient estimates for the following variables NS, FD and INV are significant. Investment is significant just in the case of regimes switching. Gross national savings lagged by one period NS it- $_{1}$ has a significant positive impact on growth. When investment in the previous year is less than or equal to the threshold of $23.6 \%$, then the budget deficit $F D_{i t-1}$ has a negative effect on growth with a coefficient estimate of -0.137. And conversely, it has a positive impact on growth with a coefficient estimate of 0.167 as the investment exceeds the defined threshold.

\begin{tabular}{|c|c|c|c|c|c|c|c|c|c|c|c|c|}
\hline \multicolumn{2}{|c|}{ Regime } & 1991 & 1992 & 1993 & 1994 & 1995 & 1996 & 1997 & 1998 & 1999 & 2000 & 2001 \\
\hline $1^{\mathrm{er}}$ & $I N V_{\text {it }-1} \leq 0.236$ & 55 & 75 & 75 & 70 & 65 & 63 & 63 & 65 & 60 & 73 & 70 \\
\hline $2^{\text {ème }}$ & $0.236<I N V_{\text {it }-1}$ & 45 & 25 & 25 & 30 & 35 & 38 & 38 & 35 & 40 & 28 & 30 \\
\hline \multicolumn{2}{|c|}{ Regime } & 2002 & 2003 & 2004 & 2005 & 2006 & 2007 & 2008 & 2009 & 2010 & 2011 & 2012 \\
\hline $1^{\mathrm{er}}$ & $I^{N N V_{i t-1} \leq 0.236}$ & 78 & 75 & 80 & 70 & 65 & 65 & 60 & 55 & 73 & 70 & 63 \\
\hline $2^{\text {ème }}$ & $0.236<I N V_{\text {it }-1}$ & 23 & 25 & 20 & 30 & 35 & 35 & 40 & 45 & 28 & 30 & 38 \\
\hline
\end{tabular}

Table 8 reports that the percentage of countries belonging to the first regime - where the ratio of total investment / GDP is below the threshold of $23 \%$ - varies from $55 \%$ to $80 \%$. Whereas the second regime where investment exceeds the threshold of $23 \%$ - the percentage ranges from $20 \%$ to $45 \%$. Hence, most countries fall into the first regime.

\subsection{THE MOROCCAN CASE}

Since we want to focus on Moroccan growth in response to the increase in the fiscal deficit, it seems useful to undertake a brief review of the historical behavior of economic growth, public debt and fiscal deficit as it will prepare the ground to lead a threshold effects analysis of fiscal policy while relying on results that were obtained previously.

\section{THE HISTORICAL BEHAVIOR OF FISCAL POLICY PUBLIC DEBT, AND GROWTH}

To draw a picture about the economic situation across the country, this sub-section presents the evolution of the following three variables ${ }^{17}$ : the general government net lending/borrowing as a percentage of nominal GDP, public debt as a percentage of nominal GDP and real GDP growth over the period 1980-2012. In Morocco, since the 1980s, the public debt increasing issue is one of the major concerns of public authorities. Figure 2 illustrates the variation of public debt (\% GDP) since 1990.

Figure 2 : Public Debt, Morocco, 1990 - 2012

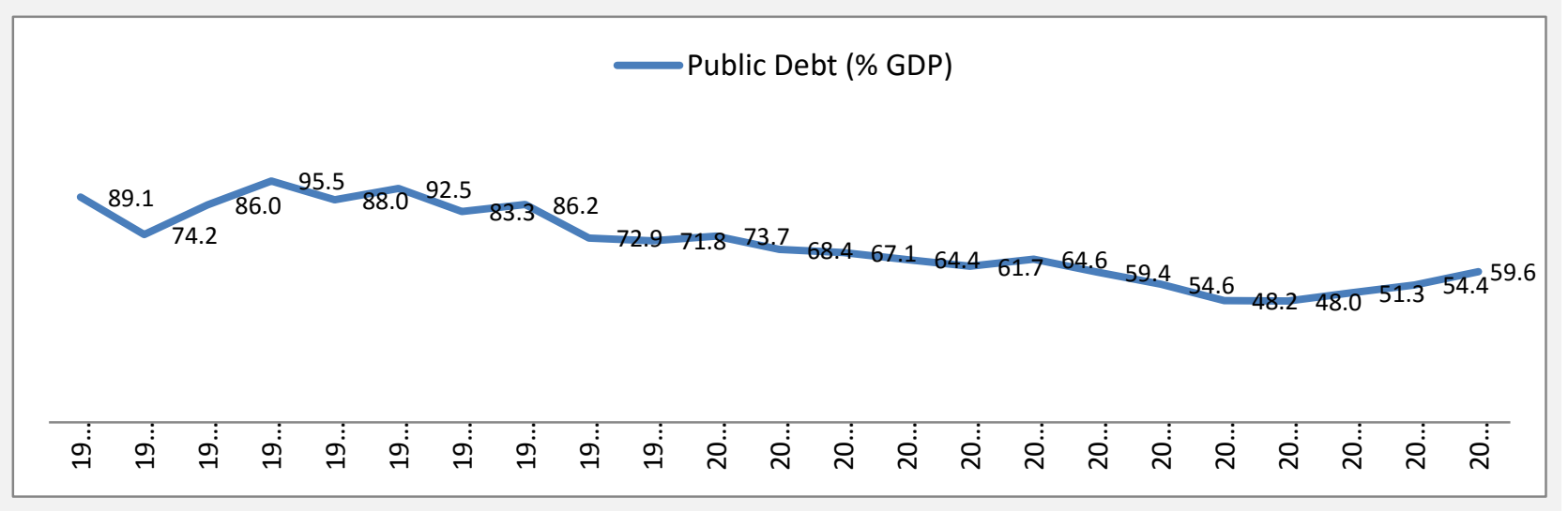

Data source: World Economic Outlook Database April 2013.

\footnotetext{
${ }^{16}$ When Student's t-test statistic is greater than the value read in the student's table (1.96 at the 5\% level and 1.64 at the $10 \%$ level), the null hypothesis of the non-significance of the parameters is rejected.

${ }_{17}$ General government net lending/borrowing or the fiscal balance is expressed in current prices, as well as public debt. Data on general government net lending/borrowing are taken from the "Haut-commissariat au Plan" database. Data on real GDP growth are taken from the IMF's "International Financial Statistics (IFS)" database. Data on public debt are taken from the IMF "World Economic Outlook Database April 2013" database and are available only from 1990. Data on nominal GDP are taken from the IMF's "IFS" database.
} 
From figure 2, three separate periods in terms of debt structure can be distinguish: the first period - which can be described as a very high debt period - varies from 1990 to 2000 and indicates a high debt level ranging from $71 \%$ to $95 \%$ of GDP with a fluctuating nature. In the second period, where it starts in 2001 and terminates in 2009, the debt ratio has declined almost persistently all over the period. The third period of 2009-2012, the public debt registered a continuous enhancement reaching 500.7 billion dirham at the end of the year 2012, which is equivalent to 59.6\% of GDP. To ease the burden of the budget deficit, the government has relied on the international financial market. It raised one billion Euros in 2010 and 1.5 billion of dollars in December 2012. The IMF granted Morocco a "precautionary and liquidity line" by an amount equivalent to 6.2 billion dirham.

Figure 3 shows the evolution of both the fiscal balance (\% of GDP) and GDP growth (annual \%):

Figure 3: GDP Growth and the Fiscal Balance, Morocco, 1980 - 2012

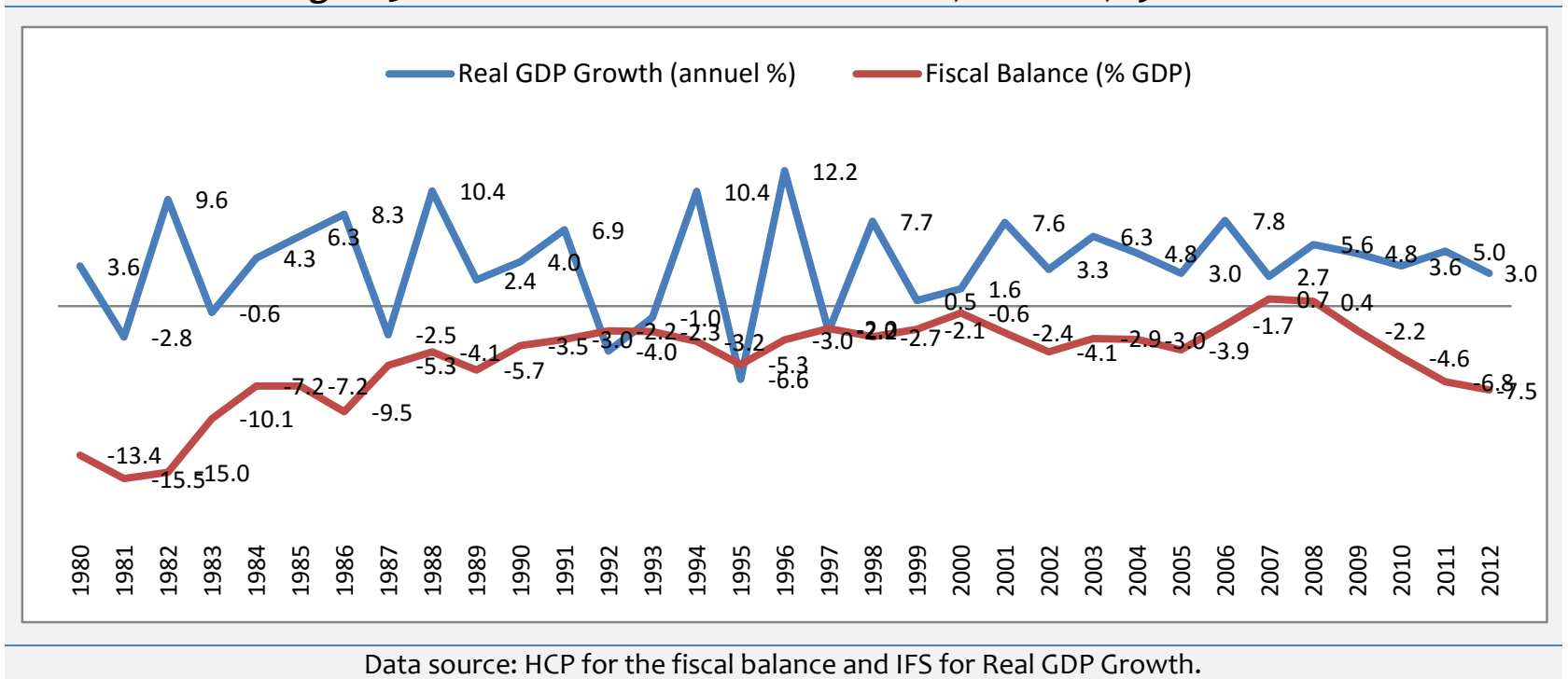

Throughout the review period, Morocco registered frequently fiscal deficits; the only notable exceptions being related to 2007 and 2008 where it is observed surplus positions of, respectively, 0.7 and 0.4 . The highest deficit was registered in 1981 ( $-15.5 \%$ of GDP). The chart shows also the chaotic behavior of economic growth, especially during the eighties and the nineties. This behavior tends to abate from 2000 onwards. This is mainly due to periodical droughts in Morocco. According the World Bank database, the Moroccan GDP was divided in 2012 to $15 \%$ in agriculture, $30 \%$ in industry and $55 \%$ in services. This division shows the substantial weight that takes agriculture in Morocco. However, since 2000, GDP growth progresses on a relatively proportional basis with the general government net lending/borrowing.

\section{MOROCCO'S THRESHOLD EFFECTS ANALYSIS ${ }^{18}$}

As a reminder, data varying between 1990 and 2012 were used for the panel estimation. However for Morocco, it seems more accurate to extend the observation period and let it cover $1980-2012$; as it will reduce the potential for error and to get a better statistical accuracy.

Figure 4 shows the variations of the fiscal balance ratio and real GDP' ${ }^{19}$ growth with two horizontal lines plotted representing the two threshold levels already found in previous analysis for the fiscal balance ratio, which are 0.032 and -0.048 .

\footnotetext{
${ }^{18}$ Reinhart and Rogoff (2010) approach has inspired me to conduct the threshold effects analysis for Morocco.

19 The key statistics and data source are provided in Appendix D.
} 


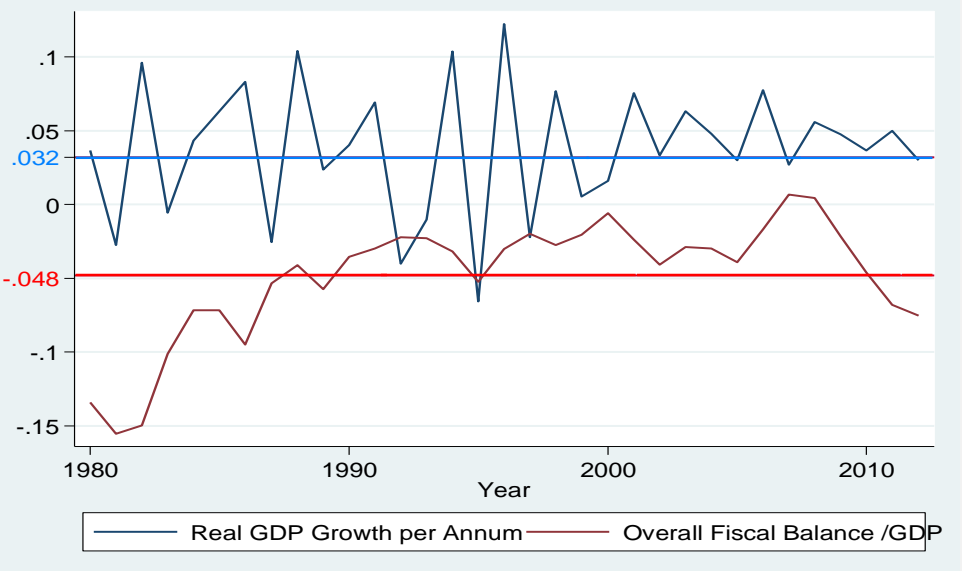

Data source: HCP for the fiscal balance and IFS for Real GDP Growth.

Over the period $1980-1987$, the budget deficit remains below the threshold level of $4.8 \%$ of GDP but with an exception for the year 1988 where Morocco has recorded a budget deficit of $2.5 \%$ of GDP. But one again, Morocco has registered a budget deficit below the threshold during 1995, 2011 and 2012. Besides that, throughout the whole considered period, Morocco's budget balance remains below the threshold of $3.2 \%$ of GDP.

\begin{tabular}{|c|c|c|c|c|c|}
\hline \multicolumn{2}{|c|}{ Regime } & \multirow{2}{*}{$\begin{array}{r}\text { Obs. } \\
12\end{array}$} & \multirow{2}{*}{$\begin{array}{l}\text { Mean } \\
0.025\end{array}$} & \multirow{2}{*}{$\begin{array}{r}\text { Median } \\
0.033\end{array}$} & Standard Deviation \\
\hline & $F B \leq-0.048$ & & & & 0.048 \\
\hline $2^{\text {nd }}$ & $-0.048<\mathrm{FB} \leq 0.032$ & 21 & 0.046 & 0.048 & 0.042 \\
\hline $3^{\text {rd }}$ & $0.032<\mathrm{FB}$ & 0 & - & - & - \\
\hline
\end{tabular}

Table 12 provides details on the behavior of economic growth as the level of budget balance varies. Morocco has never recorded a budget surplus exceeding the threshold level of $3.2 \%$ of GDP over the whole considered period 1980-2012. When the budget deficit exceeds the threshold level of $4.8 \%$, median growth falls markedly by $1.5^{20 \%}$, whereas average growth falls even heavily by $2.1 \% 21$.

\subsection{CONCLUSION}

This paper contributes to the fiscal policy literature by re-examining the relationship between the fiscal deficit and economic growth. First, the study identifies, under a linear hypothesis, the impact of five economic variables, namely the fiscal deficit, current government expenditure, national savings, inflation rate and total investment. Results shows that current government expenditure is negatively correlated with growth and thus its increase can hinder the process of growth. Raising deficit is also growth reducing. Investment has a positive sign and hence a positive effect on GDP growth. Second, examining the scatter plot in Figure 1 urged calling into question the nature of the relation between growth and the fiscal deficit as it shows an apparent non- linearity, hence the existence of threshold effects in the relationship between fiscal policy and growth is considered by using the threshold estimation approach as proposed by Hansen (1999) for non-dynamic panels. Two types of non- linearity emerged, one related to the impact of the fiscal deficit on growth, and the other involving the effects of investment. The empirical results strongly suggest the existence of a double threshold effect of the fiscal balance which is robust to their inclusion. A fiscal deficit exceeding 4.8\% of GDP drives an anti-Keynesian effect on growth, but also a fiscal surplus exceeding the threshold of $3.2 \%$ of GDP impacts negatively on economic

\footnotetext{
$201.5 \%$ is obtained from the difference between the second regime's average growth and the first regime's average growth (4.8\% $-3.3 \%=1.5 \%)$.

${ }^{21} 2.1 \%$ is obtained from the difference between the second regime's average growth and the first regime's average growth (4.6\% $-2.5 \%=2.1 \%$ ).
} 
growth. Results show also that the sign of the relationship between the budget deficit and growth is conditioned by the level of total investment: when total investment exceeds the threshold of $23 \%$ of GDP, then the budget deficit is positively correlated to economic growth with a coefficient estimates of 0.167 , whereas it is negatively correlated to growth with a coefficient estimates of -0.137 when total investment falls below this threshold. Within this framework, government budget of the countries concerned need to be monitored. These countries are expected to prevent the occurrence of deficits exceeding the thresholds found and to set priorities to reducing government final consumption expenditure in favour of productive investment. Finally, Morocco's threshold effects analysis shows that the behavior of economic growth varies depending on variations in the budget deficit: when the budget deficit exceeds the $4.8 \%$ threshold, then median growth falls sharply by $1.5 \%$, whereas average growth falls even stronger by $2.1 \%$.

While the results are instructive, some caveats are important to bear in mind when interpreting these results. First, the asymptotic distribution of the statistic $F_{1}$ on the threshold variable has a non-standard character and requires bootstrap methods to compute its significance level. Second, the estimated model does not provide the precise channels through which fiscal policy affects growth. There are also some particular issues related to data which may skew the results. Inflation rate and the current account balance show a high degree of dispersion and heterogeneity within the sample of countries. Strong asymmetry in the inflation distribution was detected as it reveals the presence of a few high values.

Several improvement extensions can be applied to the econometric approach. For future research, we could consider developing other methods where we can introduce dynamic panels in the threshold estimation approach so that one or more lags of the dependent variable "GDP growth" might be included in the model as explanatory variables. This would definitely provide solutions to the problem of omitted variables. It would be also more instructive to give more attention to the issues related to endogenous variables and to the reverse causation between economic growth and fiscal policy.

\section{ACKNOWLEDGEMENTS}

I would like to thank Pr. EL ABBASSI Idriss ${ }^{22}$, Pr. TOUNSI Said ${ }^{23}$ and Pr. HANSEN Bruce ${ }^{24}$ for the very helpful comments and suggestions.

\section{REFERENCES}

Abd Rahman N. H., (2012). How federal government's debt affect the level of economic growth? International Journal of Trade, Economics and Finance, Vol. 3, No. 4.

Adam C. S., Bevan D. L., (2005). Fiscal deficits and growth in developing countries. Journal of Public Economics, No. 89, P. 571- 597.

Aghion P., Comin D., Howitt P., (2006). When does domestic saving matter for economic growth?. NBER Working Papers, No. 12275, National Bureau of Economic Research.

Aschauer D. A., (1989). Is public expenditure productive?. Journal of Monetary Economics, No. 23, P. 177200.

Banzhaf H. S., Oates W. E., (2012). On fiscal illusion and ricardian equivalence in local public finance. NBER Working Papers, No. 18040, National Bureau of Economic Research.

Barro R., (1974). Are government bonds net wealth?. Journal of Political Economy, No. 82(6), P. 1095-1117. Barro R., (1990). Government spending in a simple model of endogenous growth. Journal of Political Economy, Vol. 98, No. 5, P. 103-125.

\footnotetext{
22 Professor, Department of economics, Mohammed V Rabat -Agdal University, Faculty of Juridical, Economic and Social Sciences, Morocco. E-mail Address: idriss elabbassi@yahoo.fr.

23 Professor, Department of economics, Mohammed V Rabat -Agdal University, Faculty of Juridical, Economic and Social Sciences, Morocco. E-mail Address: sadtounsi@gmail.com.

24 Professor, University of Wisconsin-Madison, E-mail Adress: behansen@wisc.edu.
} 
Benos N., (2009). Fiscal policy and economic growth: empirical evidence from EU countries. MPRA Paper, No. 19174, University of Ioannina.

Bertolat G. and Drazen A., (1993). Trigger points and budget cuts: explaining the effects of fiscal austerity. American Economic Review, Vol. 83, No.1, P. 11-26.

Buiter, W. H., Corsetti G., Roubini N., (1993). Excessive deficits: sense and nonsense in the Treaty of Maastricht. Economic Policy, No. 16, P. 75-100. Reprinted in the Political Economy of Monetary Union, Edited by Paul de Grauwe, P. 297-331.

Buiter W. H., (2006). The 'sense and nonsense of Maastricht' revisited: what have we learnt about stabilization in EMU?. Journal of Common Market Studies, Vol. 44, P. 687-710.

Cardia E., (1997). Replicating ricardian equivalence tests with simulated series. American Economic Review, Vol. 87, P. 65-87.

Cecchetti S. G., Mohanty M. and Zampolli F., (2010). The real effects of debt. BIS Working Papers, No. 352.

Dalamagas B.A., (1992). Testing ricardian equivalence: a reconsideration. Applied Economics, Vol. 24, Issue 1, P. 59-69.

Easterly W., Rebelo S., (1993). Fiscal policy and economic growth: an empirical investigation. Journal of Monetary Economics, No. 32, P.417-458.

Evans P., (1993). Consumers are not ricardian: evidence from nineteen countries. Economic Inquiry, Vol. 31, Issue 4, P. 534-548.

Feldstein M., (1986). The effects of fiscal policies when incomes are uncertain: a contradiction to ricardian equivalence. NBER Working Papers, No. 2062, National Bureau of Economic Research.

Ghosh S., Mourmouras I. A., (2004). Endogenous growth, welfare and budgetary regimes. Journal of Macroeconomics, Vol. 26, Issue 4, P. 623-635.

Giavazzi F., Japelli T., Pagano M., (2000). Searching for non-linear effects of fiscal policy: evidence from industrial and developing countries. European Economic Review Vol. 44, Issue 7, P. 1259-1289.

Graham, F. C., (1995). Government debt, government spending, and private sector behavior: comment. American Economic Review, Vol. 85, P. 1348-1356.

Greiner A., Semmler W., (2000). Endogenous growth, government debt and budgetary regimes. Journal of Macroeconomics, Vol. 22, Issue 3, P. 363-384.

Gupta S., Clements B., Baldacci E., Mulas-Granados C., (2005). Fiscal policy, expenditure composition, and growth in low-income countries. Journal of International Money and Finance, Vol. 24, Issue 3, P. 441463.

Hansen B., (1999). Threshold effects in non-dynamic panels: estimation, testing, and inference. Journal of econometrics, Vol. 93, Issue 2, P. 345-368.

Herndon T., Ash M., Pollin R., (2013). Does high public debt consistently stifle economic growth? a critique of Reinhart and Rogoff. PERI Working Paper Series, No. 322.

Keho Y., (2010). Budget deficits and economic growth: causality evidence and policy implications for WAEMU countries. European Journal of Economics, Finance and Administrative Sciences, No. 18, P. 99-104.

Khan M. S., Senhadji A. S., (2001). Threshold effects in the relationship between inflation and growth. IMF Staff Papers, vol. 48, No. 1.

Kotlikoff L. J., Razin A., Rosenthal R. W., (1988). A strategic altruism model in which ricardian equivalence does not hold. NBER Working Papers, No. 2699, National Bureau of Economic Research.

Minea A., Villieu P., (2008). Un réexamen de la relation non-linéaire entre déficits budgétaires et croissance économique. Presses de Sciences Po |Revue économique, No. 3, Vol. 59, P. 561-570.

Minea A., Villieu P., (2012). Persistent deficits, growth and indeterminacy. Macroeconomic Dynamics, Vol. 16, P. 267-283.

Modigliani F., Sterling A. G., (1990). Government debt, government spending and private sector behavior: a further comment. American Economic Review, Vol. 80, No. 3, P. 600-603.

Perotti R., (1999). Fiscal policy when things are going badly. Quarterly Journal of Economics, No. 114, P. 1399-1436.

Reinhart C. M., Rogoff K. S., (2010). Growth in a time of debt. American Economic Review, Vol. 100, No. 2, P. 573-578.

Reinhart C. M., Rogoff K. S., (2013). Errata, Growth in a time of debt. Harvard University. 
Tanimoune N. A., Combes J.-L., Plane P., (2008). La politique budgétaire et ses effets de seuil sur l'activité en Union Economique et Monétaire Ouest Africaine (UEMOA). La Doc. française| Economie \& prévision, Vol. 186, No. 5, P. 145-162.

\section{APPENDICES}

\section{Appendix A: Sample Countries}

Bahamas, Bangladesh, Barbados, Benin, Bolivia, Brazil, Central African Republic, Chile, Colombia, Comoros, Costa Rica, Djibouti, Dominica, Dominican Republic, Ecuador, El Salvador, Fiji, Ghana, Honduras, Hungary, India, Jamaica, Jordan, Kenya, Malaysia, Mexico, Morocco, Mozambique, Namibia, Pakistan, Poland, South Africa, Sri Lanka, Suriname, Saint Vincent and the Grenadines, Syria, Thailand, Tunisia, Uruguay, Vanuatu.

\begin{tabular}{|c|c|c|c|c|c|c|c|c|c|c|}
\hline \multicolumn{11}{|c|}{ Appendix B: Summary statistics, data for 40 developing countries } \\
\hline Variables & Mnemonic & Obs. & Mean & $\begin{array}{l}\text { Standard } \\
\text { Deviation }\end{array}$ & Median & Min. & Max. & $\begin{array}{r}\text { Total } \\
\text { Variance }\end{array}$ & $\begin{array}{r}\text { Within } \\
\text { Variance }\end{array}$ & $\begin{array}{l}\text { Between } \\
\text { Variance }\end{array}$ \\
\hline Real GDP growth & GDP & 915 & 0.036 & 0.034 & 0.040 & -0.119 & 0.148 & 0.001 & 0.001 & 0.000 \\
\hline $\begin{array}{l}\text { Ratio of current } \\
\text { government expenditure } \\
\text { to GDP }\end{array}$ & GE & 854 & 0.153 & 0.058 & 0.143 & 0.032 & 0.402 & 0.003 & 0.000 & 0.003 \\
\hline $\begin{array}{l}\text { Ratio of gross national } \\
\text { savings to GDP }\end{array}$ & NS & 849 & 0.178 & 0.077 & 0.175 & -0.061 & 0.399 & 0.006 & 0.002 & 0.004 \\
\hline $\begin{array}{l}\text { Ratio of the overall } \\
\text { budget deficit to GDP }\end{array}$ & FD & 824 & 0.031 & 0.030 & 0.030 & 0.090 & 0.130 & 0.001 & 0.001 & 0.000 \\
\hline $\begin{array}{l}\text { Ratio of total investment } \\
\text { to GDP }\end{array}$ & INV & 872 & 0.215 & 0.063 & 0.211 & 0.047 & 0.466 & 0.004 & 0.002 & 0.002 \\
\hline Inflation rate & INF & 911 & 0.113 & 0.311 & 0.056 & -0.074 & 5.858 & 0.097 & 0.085 & 0.012 \\
\hline $\begin{array}{l}\text { Ratio of the general } \\
\text { government debt to GDP }\end{array}$ & GD & 670 & 0.547 & 0.304 & 0.482 & 0.039 & 2.197 & 0.092 & 0.031 & 0.061 \\
\hline $\begin{array}{l}\text { Ratio of current account } \\
\text { balance to GDP }\end{array}$ & $\mathrm{CCB}$ & 917 & -0.039 & 0.065 & -0.032 & -0.331 & 0.171 & 0.004 & 0.002 & 0.002 \\
\hline
\end{tabular}

\section{Sources}

Data on real GDP growth, gross national savings, overall budget deficit, investment, Inflation, general government debt are taken from the IMF's World Economic Outlook database April 2013.

Data on current government expenditure are taken from the World Bank database.

\section{Definitions}

Data on current government expenditure, overall fiscal balance, gross national savings, total investment, current account balance and government's total debt are expressed in current local currency as ratios to nominal GDP. Data on inflation are expressed as annual percentages of the average consumer prices. Data on GDP growth are expressed on constant prices. General government final consumption expenditure includes all government current expenditures for purchases of goods and services (including compensation of employees). It also includes national defense and security outlays, but excludes government military spending.

Overall fiscal balance expresses a net lending (+) or borrowing (-) and measures the extent to which the government is either putting, in the event of a surplus, financial resources at the disposal of the other economic sectors and the rest of the world, or, in the case of a deficit, utilizing the financial resources generated by the other sectors and the rest of the world.

Gross national saving is calculated as gross disposable income minus final consumption expenditure after taking account of an adjustment for pension funds.

Total investment or gross capital formation is measured by the total value of the gross fixed capital formation - Gross fixed capital formation include land improvements (fences, ditches, drains, and so on), plant, machinery, and equipment purchases; and the construction of roads, railways, etc. including schools, offices, hospitals, private residential dwellings, and commercial and industrial buildings - plus net changes in the level of inventories and acquisitions of valuables.

Current account balance is the sum of net exports of goods and services, net primary income, and net secondary income.

General government debt consists of all liabilities that require payment or payments of interest and/or principal by the debtor to the creditor at a date or dates in the future. It includes domestic and foreign liabilities such as currency and money deposits, securities other than shares, and loans.

Inflation rate and real GDP growth are measured on the basis of year-on-year changes; the base year is country-specific.

\begin{tabular}{cccc}
\hline \multicolumn{3}{c}{ Appendix C: Linear model estimation } \\
\hline \multicolumn{3}{c}{ Dependant Variable: Real GDP Growth } \\
\hline & The linear models & \\
\hline Explanatory Variables & $(1)$ & $(2)$ & (3) \\
\hline
\end{tabular}




\begin{tabular}{|c|c|c|c|}
\hline GE & $\begin{array}{r}-0.159 * * \\
(2.29)\end{array}$ & $\begin{array}{r}-0.159^{* *} \\
(2.30)\end{array}$ & $\begin{array}{r}-0.119 * * \\
(2.23)\end{array}$ \\
\hline NS & $\begin{array}{l}0.099 \\
(0.84)\end{array}$ & $\begin{array}{r}0.080 * * \\
(2.41)\end{array}$ & $\begin{array}{r}0.053^{*} \\
1.88\end{array}$ \\
\hline FD & $\begin{array}{r}-0.121 * * \\
(2.14)\end{array}$ & $\begin{array}{r}-0.120 * * \\
(2.13)\end{array}$ & $\begin{array}{r}-0.201 * * * \\
4.18\end{array}$ \\
\hline INV & $\begin{array}{l}0.167 \\
(1.36)\end{array}$ & $\begin{array}{r}0.186 * * * \\
(5.68)\end{array}$ & $\begin{array}{r}0.164 * * * \\
5.75\end{array}$ \\
\hline INF & $\begin{array}{r}-0.034 \\
(1.42)\end{array}$ & $\begin{array}{r}-0.034 \\
(1.43)\end{array}$ & $\begin{array}{r}-0.042 * * * \\
3.01\end{array}$ \\
\hline GD & $\begin{array}{r}-0.006 \\
(0.95)\end{array}$ & $\begin{array}{r}-0.006 \\
(0.95)\end{array}$ & \\
\hline CCB & $\begin{array}{r}-0.020 \\
(0.17)\end{array}$ & & \\
\hline Constant & $\begin{array}{l}0.017 \\
(1.20)\end{array}$ & $\begin{array}{l}0.016 \\
(1.20)\end{array}$ & $\begin{array}{r}0.020 * * \\
2.06\end{array}$ \\
\hline Fisher Test (1) & $F(7.517)=11.76$ & $F(6.518)=13.74$ & $F(5.666)=21.62$ \\
\hline Fisher Test (2) & $F(34.517)=4.11$ & $F(34.518)=4.23$ & $F(36.666)=5.23$ \\
\hline $\mathrm{AIC}$ & -2453.441 & -2455.412 & -3092.999 \\
\hline BIC & -2418.832 & -2425.129 & -3065.624 \\
\hline $\mathrm{R}^{2}$ & 0.14 & 0.14 & 0.14 \\
\hline Number of observations & 559 & 559 & 708 \\
\hline
\end{tabular}

*** Significant coefficient at the $1 \%$ level, ** $5 \%$ and * $10 \%$.

Student's t-values are put between brackets.

Fisher Test (1) checks the significance of the explanatory variables.

Fisher Test (2) is used to examine the significance of the fixed effects.

\begin{tabular}{|c|c|c|c|c|c|c|c|}
\hline \multicolumn{8}{|c|}{ Appendix D: Summary statistics, Data for Morocco } \\
\hline Variable & Mnemonic & Obs. & Mean & Median & Standard Deviation & Min. & Max. \\
\hline Real GDP growth & GDP & 33 & 0.038 & 0.040 & 0.045 & -0.066 & 0.122 \\
\hline Ratio of the overall fiscal balance & $\mathrm{FB}$ & 33 & -0.048 & -0.035 & 0.040 & -0.155 & 0.007 \\
\hline
\end{tabular}

\section{Appendix E: Likelihood ratio function 『LR』_1( $\gamma)$ for a single threshold effect of the fiscal deficit}

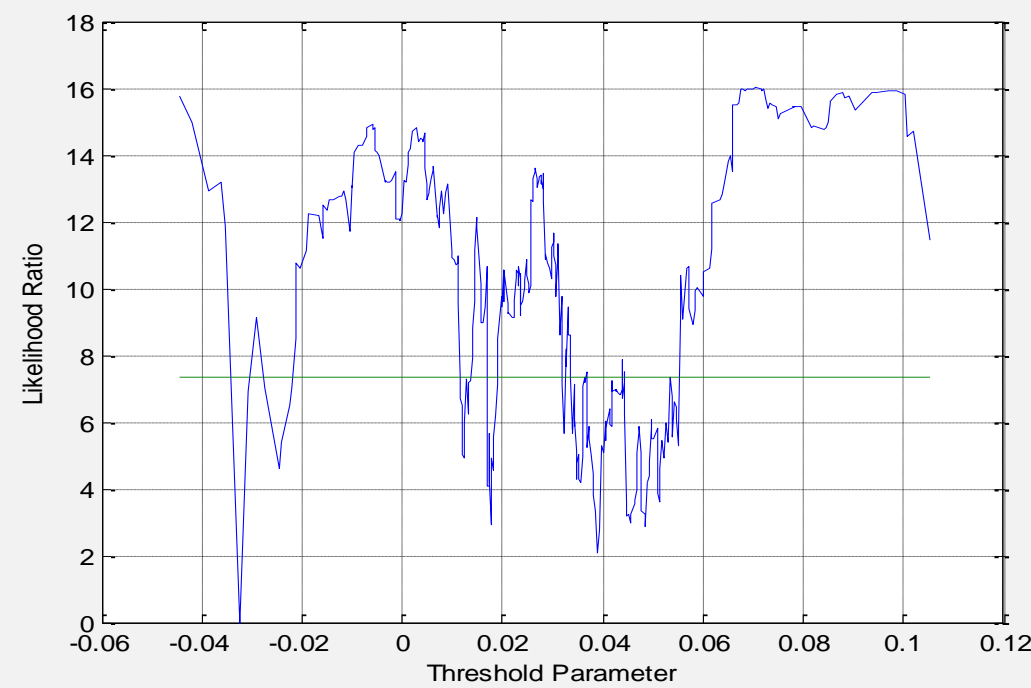


Appendix F: Likelihood Ratio Function $\mathrm{LR}_{2}^{r}(\gamma)$ for a Double Threshold Effect of the Fiscal Deficit

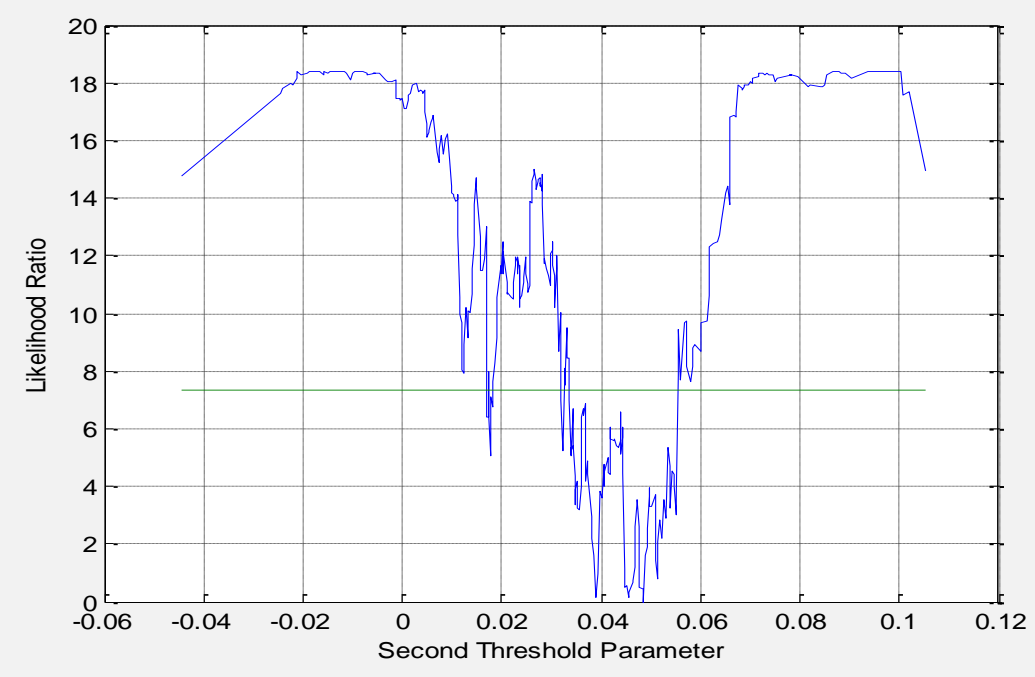

Appendix G: Likelihood ratio function $\operatorname{LR}_{1}^{r}(\gamma)$ for a double threshold effect of the fiscal deficit

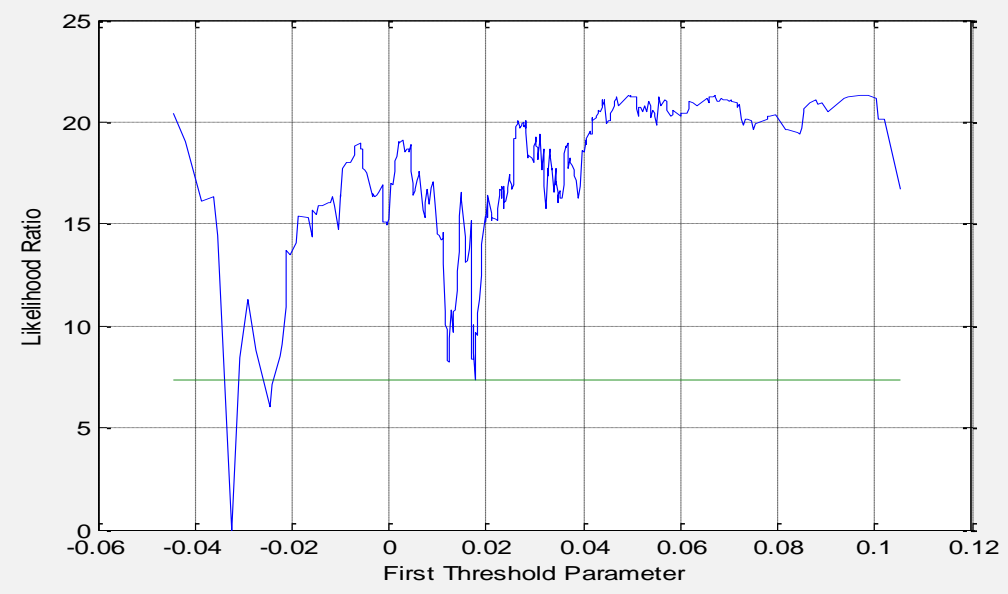

Appendix H: Likelihood ratio function 『LR】_1( $\gamma)$ for a single threshold effect of investment

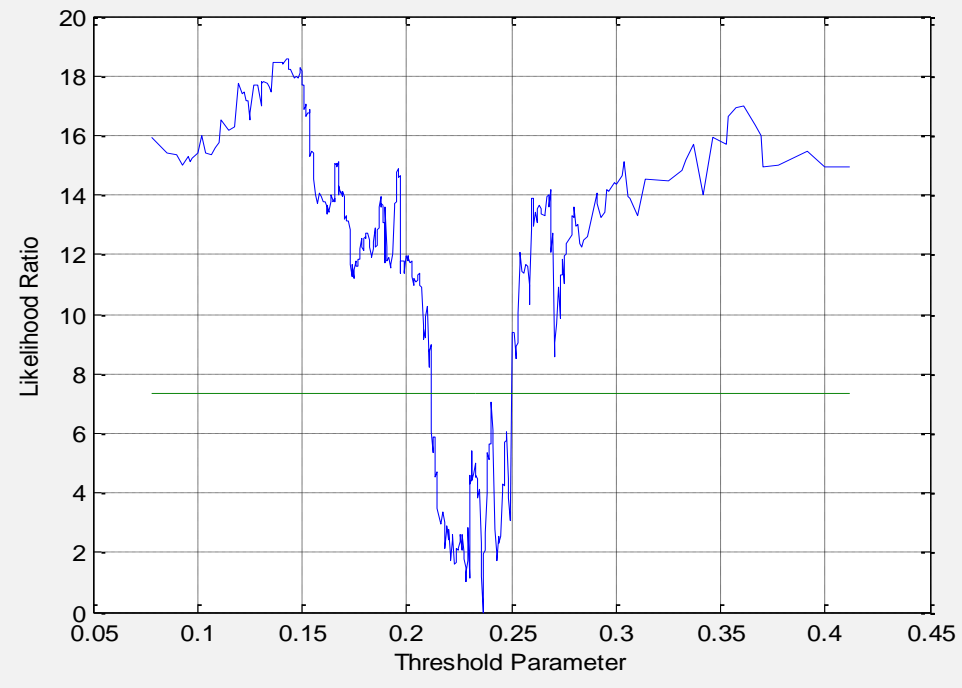

